\section{Destructive Earthquakes in 1933}

Scrence Service, Washington, D.C. (Mail Report, December 28, 1933) has issued a list of 39 earthquakes in 1933 that were strong enough to be recorded by distant seismographs. Of these, only five caused the loss of many lives. The most destructive was the Sanriku (Japan) earthquake of March 3, by which 1,560 persons were killed in addition to 956 others missing. The Long Beach (California) earthquake of March 10 was responsible for the loss of about 120 lives, the Kos earthquake of April 23 for about 100, the West Sumatra earthquake of June 24 for about 70, and the Chinese earthquake of August 25 for about 100. The Baffin's Bay 'earthquake' of November 20 would no doubt have added to the number had it not occurred in an uninhabited region. The total number of persons killed by earthquakes in 1933 is thus less than 3,000 , or less than one-half the number killed on the roads in Great Britain, and much less than the average number (about 14,000) killed by earthquakes every year (NATURE, 126, 214; 1930).

\section{Early Students' Laboratories}

WhEN Lord Kelvin opened the laboratories of University College, Bangor, in 1885, he gave an address on scientific laboratories which was printed in Nature of March 5, 1885, p. 409. He stated that the physical laboratory he started in an old wine cellar in the University of Glasgow on his appointment as professor of natural philosophy in 1845 was the first one intended for students' practical work, and that the first chemical laboratory for a similar purpose was that of Prof. von Liebig at Giessen, founded "not many years after 1831". In the November issue of the Review of Scientific Instruments, Prof. P. C. Ricketts brings forward evidence that both physical and chemical laboratories for the regular use of students were provided at Rensselaer by Amos Eaton when he became professor of chemistry and experimental philosophy there in 1824, and that "the instruction was extremely systematic and continuous".

\section{Microscopes and their Accessories}

WE have received from Messrs. W. Watson and Sons, Ltd., 313 High Holborn, London, W.C.1, a copy of the new edition of their microscope catalogue. A number of microscope stands of varying complexity are listed, and ranging in price from $£ 4$ to $£ 100$, together with ranges of objectives, eye-pieces, sub-stage fittings, etc. Several pages are devoted to a description of the principles of construction adopted by Messrs. Watson. The limb, carrying the body at one end and the sub-stage at the other, is machined from a solid casting, ensuring basic alignment throughout, and that the stage bracket is truly at right-angles to the body and sub-stage. Similarly, the tube, rib and objective fitting are machined from a solid metal billet, instead of being in three pieces as formerly, so that the risk of separation of parts is abolished, and enduring parallelism between the mechanical and optical axes is ensured. Water immersion objectives, a new low-power binocular, and new dark-ground condensers also find a place in the catalogue.

\section{Plan for Exploring Soviet Far North in 1934}

At a recent session of the Scientific Council of the All-Union Arctic Institute, plans were adopted for expeditions to the far north during this year. The plans include extensive exploration of the great northern sea route. The Moscow Daily News reports that particular attention is to be paid to the little. known Laptev and Eastern Siberian seas. Geological expeditions will aim at creating a fuel base for ships navigating the great northern sea route and at discovering ores of non-ferrous and rare metals. Their attention will therefore be concentrated on Novaya Zemlya, the eastern part of the Chukotsk peninsula and Northern Land, where indications of oil, coal and ores have been found. Geodetic expeditions with an aeroplane at their disposal will carry out preparatory work for compiling the first $1: 1,000,000$ map of the Soviet Arctic, to be published in 1937. Five new permanent research stations will be added to the existing twenty, and a new laboratory for the study of magnetic phenomena will be erected near the estuary of the Kolyma. Attention is to be paid to the study of reindeer and polar dog breeding. Special breeding farms are to be organised in order to facilitate communication between the stations along the northern sea route.

\section{Pumps at the Science Museum}

The plan now being followed at the Science Museum, South Kensington, is to publish handbooks of two kinds; one containing historical notes, and the other containing details of the exhibits. Some time ago we directed attention to the new volume of "Historical Notes on Pumping Machinery" and we now have pleasure in referring to the new "Descriptive Catalogue". Like the former, this has been prepared by Mr. G. F. Westcott. The notes placed alongside the exhibits in the Science Museum have long been known for their fullness and their accuracy, and the "Descriptive Catalogue" contains more than five hundred of these notes together with many excellent illustrations. The pumping machinery collections are divided into about twenty groups and the exhibits range from the most primitive baling appliances to large turbo-blowers and the mercury vapour vacuum pumps of Gaede and Langmuir. The price of the new volume is $3 s .6 d$., so that for $6 s$. the reader can obtain both handbooks, which together contain more precise information on pumps of all kinds than can, we believe, be found in any other publication. The compiling of such catalogues involves a very great amount of research and Mr. Westcott is to be con. gratulated in having brought his task to a successful conclusion.

\section{Medals of the Institution of Chemical Engineers}

AT the twelfth annual corporate meeting of the Institution of Chemical Engineers on February 16, presentation will be made of the Moulton medal, the 
Junior Moulton medal and prize of books, and the Osborne Reynolds medal, all of which were instituted in 1929. The Moulton medal, which commemorates the chemical engineering work of the late Lord Moulton at the Department of Explosives Supply, is awarded for the best paper of each year presented before the Institution. Papers by non-members of the Institution are eligible for this medal. For 1933 the award is made for the following papers: "The Mechanical Properties of some Austenitic Stainless Steels at Low Temperatures", by Messrs. E. W. Colbeck, W. E. MacGillivray and W. R. D. Manning ; and "The Mechanical Properties of Metals at Low Temperatures. (2)-Non-Ferrous Materials", by Messrs. E. W. Colbeck and W. E. MacGillivray. The Junior Moulton medal is given for the best paper of the year read before the Graduates and Students Section of the Institution. Only papers by graduates and students of the Institution are considered for this medal and prize. For 1933 the award is made for the paper : "The Solvent Extraction of Sulphur from Sicilian Ores", by Dr. E. H. T. Hoblyn. The Osborne Reynolds medal commemorates the fundamental investigations of the late Prof. Osborne Reynolds, and is awarded for meritorious service for the advancement of the Institution. For 1933 the award is made to Mr. H. W. Cremer. Mr. Cremer acted as honorary secretary of the Institution during the illness of the late Prof. J. W. Hinchley in 1931, and was appointed to succeed Prof. Hinchley in that office on the latter's death.

\section{Announcements}

H.R.H. The Prince of Wales has consented to become patron of the London School of Hygiene and Tropical Medicine, with which is incorporated the Ross Institute.

THE Catherine Wolfe Bruce gold medal of the Astronomical Society of the Pacific for the year 1934 has been awarded to Prof. Alfred Fowler, Yarrow research professor of the Royal Society and professor of astrophysics in the University of London (Imperial College of Science), for his distinguished service in the field of astronomy.

THE council of the Institution of Electrical Engineers has made the twelfth award of the Faraday medal to Sir Frank E. Smith, secretary of the Department of Scientific and Industrial Research. The Faraday medal is awarded either for notable scientific or industrial achievement in electrical engineering or for conspicuous service rendered to the advancement of electrical science, without restriction as regards nationality, country of residence, or membership of the Institution. Dr. R. Thury, of Geneva, has been elected an honorary member of the Institution.

Mr. C. S. WRIGHT, superintendent of the Admiralty Research Laboratory at Teddington, has been appointed as from July 8 to be director of scientific research, Admiralty, in succession to Dr. C. V. Drysdale.
Prof. Hans Fischer, professor of organic chemistry and Privatdozent in plant physiology in the Bavarian Technical High-school, Munich, will deliver the fourth Pedler lecture before the Chemical Society on Thursday, February 22, at 8 p.m., in the lecture theatre of the Royal Institution. The title of Prof. Fischer's lecture will be "Chlorophyll". Admission to the lecture will be free without ticket.

A Conference on "Problems of Potato Growing" will be held at the Rothamsted Experimental Station, on Tuesday, February 20, at 11.30 a.m. The chair will be taken by Capt. J. Mollett, chairman of the Potato Marketing Board. Papers on problems in potato cultivation will be read by Drs. G. H. Pethybridge, R. T. Leiper, H. E. Woodman, E. M. Crowther, and Mr. H. V. Garner. Further information can be obtained from the Secretary, Rothamsted Experimental Station, Harpenden.

Writh the issue on January 5 , the Deutsche Medizinische Wochenschrift entered the sixtieth year of its existence. It contains several important articles, notably one on rheumatic diseases by Prof. Aschoff, and another by Prof. Heine on inflammatory conditions of the iris, with an excellent coloured plate.

A volume of "Abstracts of Dissertations approved for the Ph.D., M.Sc. and M.Litt. Degrees in the University of Cambridge during the Academical Year 1932-1933"' (Cambridge University Press, 1933) has been issued, the summaries having been approved by the examiners or by the student's supervisor. By this means, the nature of research work which might otherwise be overlooked for a time is made easily accessible, and copies of the dissertations can be consulted if desired in the University Library or at the University Registry.

Applications are invited for the following appointments, on or before the dates mentioned:-An agricultural chemist at the Imperial Institute of Agricultural Research, Pusa-The High Commissioner for India, General Department, India House, Aldwych, London, W.C.2 (Feb. 12). A curator of the Wakefield Museum and Art Gallery-The Town Clerk, Town Hall, Wakefield (Feb. 17). A borough engineer to the Metropolitan Borough of HackneyThe Town Clerk, Town Hall, Hackney, E.8 (Feb. 17). An inspector in connexion with agricultural and horticultural education and research-The Secretary, Ministry of Agriculture and Fisheries, 10, Whitehall Place, S.W.1 (Feb. 26). A temporary veterinary officer to the Lancashire County Council-The Clerk of the County Council, County Offices, Preston (Feb. 28). A bacteriologist and clinical pathologist at Queen's Hospital, Birmingham - The House Governor (March 5). A City bacteriologist to the City Council and professor of bacteriology in the University of Liverpool (joint appointment)-The Registrar, The University, Liverpool (April 14). An assistant in the Museum at the Royal Botanic Garden, Edinburgh-The Regius Keeper. 